American Journal of Agricultural and Biological Sciences 5 (1): 7-14, 2010

ISSN 1557-4989

C 2010 Science Publications

\title{
Lisrel Analysis of Factors for Empowering Producers to Abolish Livelihood Poverty through Optimizing Agricultural Water Resources Management
}

\author{
${ }^{1}$ Fatemeh Panahi and ${ }^{2}$ Iraj Malekmohammadi \\ ${ }^{1}$ Dezful Branch, Islamic Azad University, Agriculture College, Dezful, Iran \\ ${ }^{2}$ Tehran University, Karaj, Iran
}

\begin{abstract}
Problem statement: Most of the projected increase in global population will take place in third world countries that already suffer from water, food, and health problems. Irrigation in developing countries tends to be stereotyped as equity reducing, in competition with other uses for scarce water resources. Agricultural intensification through the practice of irrigation as a strategy for poverty reduction is examined. Water users were surveyed in order to explore their perception about the factors influencing the optimizing water consumption in agricultural sectors in Iran. This study looks into water-poverty interfaces as well as into approaches to and tools of, managing water in such a manner that water sector activities can contribute to alleviation of poverty. In addition, this study aims to empower water users with information on agricultural wastewater. Approach: The methodology used in this study involved a combination of descriptive and quantitative research. The total population was 350 producers in six provinces in Iran. Results: Based on the perception of the respondents and ordinal factor analysis, the factors were categorized into four group's namely technical and practical, recognition and managing water equipment and constructive ordered by the magnitude of their impact. The total variance explained by these 4 factors is $54.27 \%$ as effective mechanisms in optimizing agricultural water resources management. Structural equation model is expected to be useful for designing targeted optimizing agricultural water resources management and poverty alleviation strategies that also enhance agricultural-productivity growth. Conclusion/Recommendations: Where there is equity in resource distribution, the impact of improved water management on agricultural productivity growth has been more poverty reducing. Using water better means improving the productivity of agricultural water in both irrigated and rainfed systems, through multiple-use water system, integrated water resources planning, and targeted research.
\end{abstract}

Key words: Empowering producers, abolish poverty, water management, Waste water management, rural livelihood, agricultural water

\section{INTRODUCTION}

UNDP (2004) pointed out agriculture is now and will continue to be a key source of livelihood for lowincome countries and the poor who live there. In these countries, $80 \%$ of export earnings come from the agricultural sector, which uses more water than any other enterprise. As stated by Takashi (2001), agriculture is the major economic sector in most developing countries.

Water has been predicted to be the oil of the twenty-first century, meaning that successful water management will be the key to future economic growth and social wealth in both developed and developing countries (Clothier, 2000).

The World Bank showed that Agricultural Water Management (AWM) is not a goal in itself but part of a process of resource management that provides critical input to agricultural production and farmer incomes (Vinod, 2006).

Iran contains both arid and semiarid regions with an annual average precipitation of $250 \mathrm{~mm}$, which is less than one-third of the global average. Currently, total water consumption is approximately $88.5 \mathrm{bm}^{3}$ year, of which more than $92-94 \%$ is used in agriculture and less than $7 \%$ is allocated to urban and industrial consumption. In total, $82.5 \mathrm{bm}^{3}$ of water is utilized for irrigation on 7.8 million ha of cultivated land.

The irrigation potential in Iran is estimated at 37 million ha, with only 7.8 million ha currently receiving irrigation water, representing $21 \%$ of the potential. Of the total arable land, about one-third is irrigated by traditional systems. Keshavarz et al. (2003) observed

Corresponding Author: Fatemeh Panahi, Dezful Branch, Islamic Azad University, College of Agriculture, Dezful, Iran Tel: +98-9173521823 
that overall irrigation efficiency in Iran ranges from $33-37 \%$, lower than the average for both developing countries (45\%) and developed countries (60\%).

As Malakmohammadi (2009) stated, in the most vulnerable areas of the world such as Asia and Pacific Region that accounts for $57 \%$ of the world's population (nearly 3.2 billion), about half of that population will be younger than 25 in 2010 , more than $80 \%$ of the world's smallholder farmers and $73 \%$ of the total farming households live in, two-thirds of the world's hungry and poor are found here, 800 million people who are poor and 500 million of them who are malnourished.

Iran's population is approximately 70.495 million, of whom $31.36 \%$ live in rural regions, $23.4 \%$ of the total population is classified as active in the agricultural sector and this percentage is equivalent to 3.611 million people of the 23.469 million active in the economic sector (SCI, 2007). It has been estimated that Iran's population will reach 90 million by the year 2020 (Raghfar, 2007). Such an increase would require 172 million tons of agricultural production from irrigated land (Keshavarz et al., 2003).

In 2004 , the poverty line rose to $29 \%$ in rural states and to $28 \%$ in urban areas. Thus, the proportion of people classified as poor has increased since 2004 (Raghfar, 2007).

More than $90 \%$ of the renewable water in the country is used for agriculture, but the sector still cannot produce enough to meet the demands of the population. Currently, agricultural products from irrigated farming total 56 million tons.

The amount of water used for irrigated agriculture is $83 \mathrm{bm}^{3}$, so water productivity is $0.7 \mathrm{~kg} \mathrm{~m}^{-3}$. To supply adequate food in 2020, agricultural production will have to increase to 160 million tons. So by the year 2020, water productivity will have to increase to $1.6 \mathrm{~kg} \mathrm{~m}^{-3}$. Therefore, it is important to focus on using water efficiently through improved irrigation and water management.

Iranian agriculture has suffered from inefficient resource management by actors within the sector, rather than by limited natural resources. Thus, it is essential to give more consideration to human resources in the agricultural sector.

Since farmers and water users are the primary active human resources in the agricultural sector, it is necessary to increase their competence in order to improve the efficiency and productivity of farming. Today, this is becoming increasingly important because of the competitiveness within the sector.

Ommani (2008) referred to Evenson as he said agricultural extension and education will impact the economics and sustainability of agriculture by providing information to induce farmers' awareness and knowledge through testing and experimentation, farmers' adoption of new technology or practices and changes in farmers' productivity.

Malakmohammadi (2009) pointed out, agricultural extension is a public service for Human Resource Development (HRD) in the agricultural sector. Although extension is not the magic wand that will change agriculture overnight. Nonetheless, extension will impact human capital development through agricultural literacy, thus enhancing economic growth (Malakmohammadi, 2009).

Prior research: Ward et al. (2005) showed that agriculture in most locations generates the lowest value added per unit of water compared to other water-using sectors. Within the agricultural sector, however, there are numerous ways to improve the return on investments in water. Higher return on water investments will boost incomes for farmer.

FAO (2003) reveal that for improving irrigation management, efforts are focused on the empowerment of water users associations and their involvement in resource management.

Rahaman et al. (2004) and Biswas et al. (2003) assert that to be effective, water management must take a holistic approach, linking social and economic development with the protection of natural ecosystems.

As stated by Shen and Varis (2000), the water resource management crisis is the result of poor management rather than of modern technologies. Technology-oriented management should be balanced with human-oriented management (Ahmad, 2003).

Akpabio et al. (2007) pointed out that equitable resource allocation, efficient and balanced resource use, participation of stakeholders in decision making and recognition of linkages and interactions among human and physical systems are key principles in integrated water resource management.

Giordano (2007) believes that the increasing pressure on agricultural water use comes at a time when rural poverty reduction and national food security are major national goals.

Hussain et al. (2006) showed that negative social and environmental consequences often hurt the poor more than the non poor because the poor lack political power and the financial resources to avoid the potentially adverse impacts of irrigation, from physical displacements to health risks and land degradation.

Akpabio et al. (2007) reported that irrigation can increase the yields of most crops. Furthermore, irrigation leads to less risky and more continuous levels of rural employment and income. Irrigated as compared 
to rain-fed agriculture is conducive to higher cropping intensities that improve yields, allowing the cultivation of higher-value crops and the use of sophisticated cultivation techniques (Smith, 2004).

Water resources development and management play a fundamental role in sustainable growth and poverty reduction (Molden et al., 2007; Hussain and Hanjra, 2003; 2004; Varma et al., 2006; Rijsberman et al., 2006; Rijsberman, 2003).

Hussain et al. (2004) assert that there are five key dimensions of the relationship between access to good agricultural water and socioeconomic improvement in rural areas: production, income, consumption, employment, vulnerability, food security and overall welfare. Hussain (2004) maintains that irrigation can influence poverty through three pathways: (a) micropathway; (b) meso-pathway and (c) macro-pathway.

Carriger (2005) showed that research has confirmed that irrigation development does reduce poverty.

\section{MATERIALS AND METHODS}

The methodology used in this study involved a combination of descriptive and quantitative research. The population of this study included producers, $(\mathrm{N}=220000)$ in selected six provinces, of which 350 producers was selected. Research based on the Cochran formula and using stratifies random sampling and questionnaires. Face validity was established by a panel of experts consisting of faculty members and graduate students at Tehran University, Tarbiat Modares University and Islamic Azad University, Iran. A pilot test was conducted with 30 producers. Questionnaire reliability was estimated by calculating Alfa Cronbach and Compose Reliability methods by Spss and Lisrel software. Reliability for the overall instrument was estimated at 0.85 and $0.68 \%$ respectively.

\section{RESULTS}

The results of descriptive statistics show that most of the producers in the research were the men $(98.3 \%)$ who are the annual income rate and income from agriculture were 131700 and 102100 thousand Rials, respectively.

The average of annual expenses for the producer's family is 106600 thousand Rials and the expense for more than $30 \%$ of the study population is less than 50 million Rials.

It was reported that slightly more than $30 \%$ of producers had primary school degree whose maximum level of literacy was bachelor.

Over $80 \%$ of the producer families holding own land and only $18.9 \%$ having agricultural land and laborer.

Amount to $56 \%$ of the producers possess less than 5 hectares of irrigated farming land and $69.4 \%$ having below 3 tracts of irrigated land.

Deep-well is the irrigation resource for most of the research answerers and only $28 \%$ of them using two or more water resources for irrigate. More than $70 \%$ of the producers using canal irrigation and only $1.7 \%$ using rain method of irrigation in addition.

The average share of water for each producer is 2.5 units. $68 \%$ of the producers owning the water resource individually and for most of them, the resource is located in the farm field or around.

The capability of producers in utilizing the mechanism of agriculture water resources management was very low and most of them believe that the efficiency of these mechanisms is very high.

From the producer's point of view, acting according to the extension advices, Adjusting irrigation canal deficiencies and leveling land as the principles of water resources management, has systematic priority in resources, transferring and the farm.

According Table 1, from the viewpoint of the producers, restoring and renovation of canals has the initial priority in agriculture water management activities done by the government.

From the viewpoint of the producers, visiting the agent in the service centers in order to perform extension programs in agriculture water management has the initial priority (Table 2).

Table 1: Ranks of activities done by the government to manage agriculture water resources

\begin{tabular}{llll}
\hline Factors & Median & SD & CV \\
\hline Restoring and renovation of canals & 3 & 1.348 & 0.449 \\
Digging new wells & 2 & 1.578 & 0.789 \\
Repairing old wells & 2 & 1.714 & 0.857 \\
Restoring and renovation of springs and related rivers & 1 & 1.443 & 1.443 \\
Constructing deviation dams and the related canals on rivers & 1 & 1.521 & 1.522 \\
Dredging aqueduct & 1 & 1.521 & 1.522 \\
Pool reserves for agriculture water purposes & 1 & 5 & 1.565 \\
\hline
\end{tabular}


Am. J. Agri. \& Biol. Sci., 5 (1): 7-14, 2010

Table 2: Ranks of extension services in order to cure the agriculture water management

\begin{tabular}{|c|c|c|c|c|}
\hline Factors & Median & SD & $\mathrm{CV}$ & Rank \\
\hline Visiting the agent in the service center & 2 & 1.501 & 0.750 & 1 \\
\hline Scientific tour on visiting irrigation methods & 1 & 1.383 & 1.383 & 2 \\
\hline To study magazines & 1 & 1.451 & 1.451 & 3 \\
\hline Participating in extension courses & 1 & 1.463 & 1.463 & 4 \\
\hline Visiting the agent in the village & 1 & 1.472 & 1.472 & 5 \\
\hline
\end{tabular}

Table 3: The quantities of standard parameters in factor analysis of obstacle in utilizing optimizing agriculture water resources management

\begin{tabular}{|c|c|c|c|c|c|c|}
\hline Latent variable & Observed variables & SS & $\mathrm{R}^{2}$ & $\mathrm{t}$ & $\mathrm{E}$ & Variance by factor \\
\hline \multirow{11}{*}{ Economical and finance } & $\begin{array}{l}\text { High cost sprinkler irrigation system (installation } \\
\text { and maintenance) }\end{array}$ & 0.75 & 0.52 & 14.15 & 0.053 & \multirow{11}{*}{13.400} \\
\hline & High cost of converting traditional canals & 0.77 & 0.61 & 15.59 & 0.055 & \\
\hline & & & & & & \\
\hline & Government weak policies & 0.78 & 0.58 & 11.58 & 0.048 & \\
\hline & Shortages in the credits & 0.79 & 0.64 & 10.22 & 0.066 & \\
\hline & Shortage in assisting services & 0.61 & 0.37 & 11.87 & 0.055 & \\
\hline & Lack of insurance for irrigation systems & 0.62 & 0.39 & 8.750 & 0.070 & \\
\hline & Shortage in irrigation equipment & 0.61 & 0.31 & 10.79 & 0.061 & \\
\hline & Subside allocation of water in agriculture & 0.58 & 0.33 & 15.06 & 0.057 & \\
\hline & Effects of digging deep wells on dryness semi deep wells & 0.64 & 0.34 & 10.15 & 0.070 & \\
\hline & No drainage system usage & 0.76 & 0.62 & 8.750 & 0.070 & \\
\hline \multirow[t]{5}{*}{ Planning } & & & & & & \multirow[t]{5}{*}{11.890} \\
\hline & No usage of agriculture water drainage & 0.73 & 0.56 & 13.03 & 0.074 & \\
\hline & Inconsistency between the number of wells and field area & 0.64 & 0.33 & 10.03 & 0.069 & \\
\hline & Salinity land & 0.71 & 0.36 & 10.46 & 0.078 & \\
\hline & Unawareness on low benefit in traditional methods & 0.70 & 0.49 & 11.00 & 0.490 & \\
\hline \multirow[t]{5}{*}{ Extension and education } & & & & & & \multirow[t]{5}{*}{9.360} \\
\hline & No acceptance of modern irrigation systems & 0.71 & 0.51 & 11.90 & 0.110 & \\
\hline & Unawareness of modern irrigation technologies & 0.79 & 0.63 & 12.94 & 0.110 & \\
\hline & Lack of irrigation specialists expert & 0.64 & 0.41 & 10.75 & 0.085 & \\
\hline & Scattering of land tracts & 0.51 & 0.56 & 3.340 & 0.460 & \\
\hline \multirow[t]{2}{*}{ Natural } & & & & & & 5.900 \\
\hline & Common water resource & 0.60 & 0.24 & 8.360 & 0.120 & $40.56 \%$ \\
\hline
\end{tabular}

By using Lisrel 8.5 software, ordinal factor analysis have been done to know the obstacle factors in optimizing agriculture water resources management and consequently abolish poverty and it was clear by using the statistics on constructive equations that, the best analysis is the factor analysis having 4 factor and Logit function. As it is observed in the Table 3, finance and economic problems, planning, extension and education and natural are the four grades in the correct management of agriculture water resources.

The total variance explained by these four factors is $40.56 \%$ in an incorrect management of agriculture water resources and the rest of variance explained by the other factors not included in the research (Table 3).

Model fit range from acceptable (RMSEA) to weak $\left(\mathrm{X}^{2} / \mathrm{df}\right.$ ratio and $\mathrm{p}$ - value) to good (CFI, GFI, AGFI and NFI (Table 4 and Fig. 1).

Table 5 shows the grouping, arrived at by using ordinal factor analysis in SEM of the factors into four latent variables, namely technical and practical, recognition, managing water equipment and constructive.
Table 4: Suitability indicators in factor analysis obstacle factors in utilizing best management of agriculture water usage

\begin{tabular}{lr}
\hline Goodness of fit test & Amount \\
\hline Normal theory weighted least squares chi-square & 384.61 \\
P-value & 0.03 \\
Degrees of freedom & 142.00 \\
Root Mean Square Error of Approximation (RMSEA) & 0.07 \\
Comparative Fit Index (CFI) & 0.96 \\
Normal Fit Index (NFI) & 0.94 \\
Goodness of Fit Index (GFI) & 0.90 \\
Adjusted Goodness of Fit Index (AGFI) & 0.86 \\
\hline
\end{tabular}

The basic idea of factor analysis is to find a set of latent variables that contain the same information. The classical factor analysis assumes that both observed and latent variables are continuous variables but, in practice, the observed variables are often ordinal.

The total variance explained by these four factors is $54.27 \%$ as effective mechanisms in optimizing agricultural water resources management and the rest of variance explained by the other factors not included in the research.

Spearman coefficient was employed for measurement of relationships between the ability of producers in optimizing agriculture water resources 
management and factors which influencing the empowerment in water resources management. Table 6 displays the results which show that there were relationship between ability of respondents about optimizing agriculture water resources management and the total incoming, education level, size of the farm, share of water resource, technical knowledge, attitude on management of water resources, extension programs perform in agriculture water management and rate of cooperation between the producers and related organizations in water management. The findings also indicated that there was no relationship between the number of irrigated land tracts and length of farm water canal.

The quantities of standard parameter for each factor, shows their pressure on the variance that indicating the amount of $t>2$ and their share in the measurement of variance Table 7 and 8).

The bivariate correlation between the latent variable poverty and agriculture water management would be $\mathrm{SS}=0.49$. The Adjusted $\mathrm{R}$ Square $\left(\mathrm{R}^{2}\right)$ explained by these factors is $46 \%$ and the rest of $\mathrm{R}^{2}$ explained by the other factors not included in the research (Table 9).

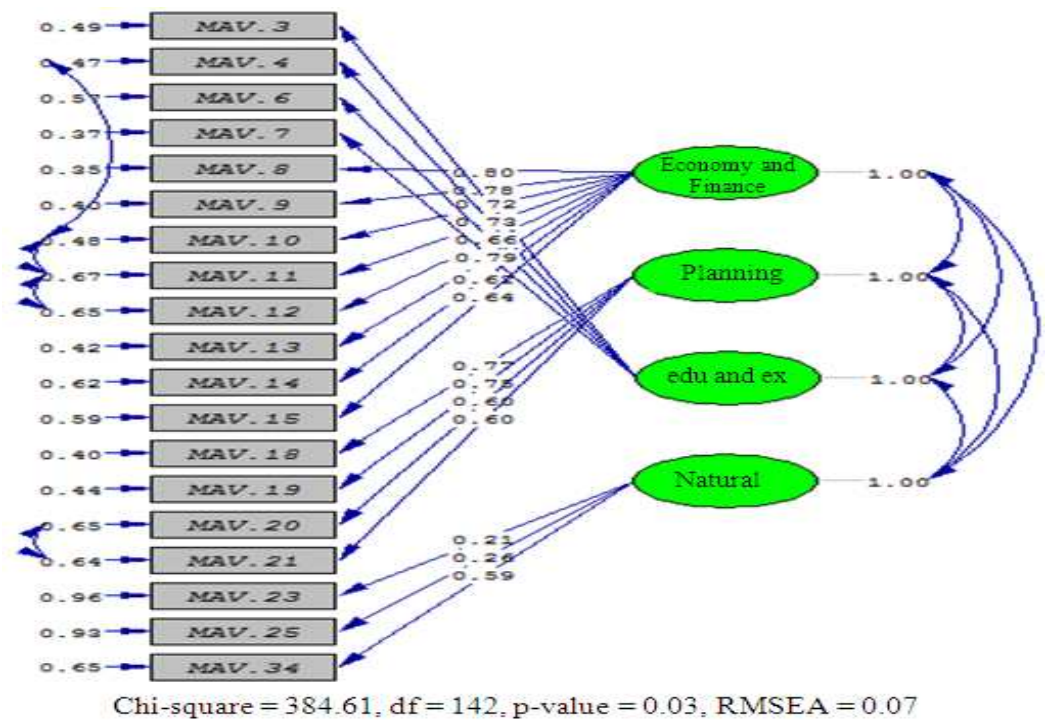

Fig. 1: X model of obstacle factors in utilizing best management of agriculture water usage

Table 5: Factor analysis of effective mechanism in empowering producers in agriculture water resources management

\begin{tabular}{|c|c|c|}
\hline Latent variable & Observed variables & Variance by factor \\
\hline $\begin{array}{l}\text { Technical } \\
\text { and practical }\end{array}$ & $\begin{array}{l}\text { Conservation irrigating systems, Installation of modern irrigation systems, } \\
\text { using of discharge measurement equipment, acting according to the extension advices, canal lining }\end{array}$ & 15.94 \\
\hline Recognition & $\begin{array}{l}\text { Plan consumption water use equal to irrigation level, Cultivating low and high water plants simultaneous, } \\
\text { familiarity with assigning water }\end{array}$ & 14.77 \\
\hline $\begin{array}{l}\text { Managing } \\
\text { water } \\
\text { equipment }\end{array}$ & $\begin{array}{l}\text { Unawareness of traditional methods low efficiency on low benefit in traditional methods, } \\
\text { low acceptance of modern systems, unawareness of modern irrigation technologies, } \\
\text { lack of irrigation specialists expert }\end{array}$ & 14.27 \\
\hline $\begin{array}{l}\text { Constructive } \\
\text { Total }\end{array}$ & Sattering of land tract, common water resources & $\begin{array}{c}9.41 \\
54.27 \%\end{array}$ \\
\hline Total & & \\
\hline
\end{tabular}

Table 6: Correlation measures employment between research factors and ability of producer in agriculture water resources management

\begin{tabular}{llr}
\hline Factors & $\mathrm{r}$ & $\mathrm{Sig}$ \\
\hline Education level & $0.123^{*}$ & 22.000 \\
Total incoming & $0.162^{*}$ & 0.002 \\
Number of irrigated land tracts & 0.132 & 0.081 \\
Size of the farm & $0.126^{*}$ & 0.019 \\
Share of water resource & $0.117^{*}$ & 0.029 \\
Length of farm water canal & 0.082 & 0.126 \\
Technical knowledge & $0.326^{* *}$ & $0.281^{* *}$ \\
Attitude on management of water resources & $0.289^{* *}$ & 0.000 \\
Agriculture water management activities done by the government & $0.640^{* *}$ & 0.000 \\
Extension programs perform in agriculture water management & $0.194^{* *}$ & 0.000 \\
Rate of cooperation between the producers and related organizations in water management & & 0.000 \\
\hline
\end{tabular}

**: $\mathrm{p}<0.01, *: \mathrm{p}<0.05$ 
Am. J. Agri. \& Biol. Sci., 5 (1): 7-14, 2010

Table 7: The quantities of standard parameters for X model (the wealth of producers and also water resource management)

\begin{tabular}{|c|c|c|c|c|c|}
\hline Latent variable & Observed variables & SS & $\mathrm{R}^{2}$ & $\mathrm{t}$ & $\mathrm{E}$ \\
\hline \multirow[t]{2}{*}{ Producers } & Size of garden & 0.63 & 0.39 & 11.77 & 0.590 \\
\hline & Size of farm & 0.80 & 0.64 & 17.36 & 1.640 \\
\hline Property & Dry farming land under cultivation & 0.72 & 0.52 & 14.51 & 0.310 \\
\hline \multirow{2}{*}{ and wealth } & Number of irrigating resources & 0.60 & 0.36 & 12.25 & 0.090 \\
\hline & Share of water resource & 0.42 & 0.18 & 8.34 & 0.140 \\
\hline Agriculture & Capability of producers in managing agricultural water & 0.60 & 0.36 & 8.20 & 0.048 \\
\hline Water & The producers viewpoint in the affairs of agriculture water resources management & 0.35 & 0.12 & 4.97 & 0.059 \\
\hline Management & Obstacles in managing agriculture water & 0.60 & 0.36 & 8.00 & 0.060 \\
\hline
\end{tabular}

Table 8: The quantities of standard parameters for model (poverty)

\begin{tabular}{llllr}
\hline Latent variable & Observed variables & SS & $\mathrm{R}^{2}$ & $\mathrm{t}$ \\
\hline Poverty & Income level & 0.95 & 0.89 & 3.96 \\
& Life expenses & 0.84 & 0.73 & 0.081 \\
& & & 0.480 \\
\hline
\end{tabular}

Table 9: The quantities of standard parameters for model (poverty)

\begin{tabular}{llll}
\hline Path & $\mathrm{SS}$ & $\mathrm{R}^{2}$ & $\mathrm{E}$ \\
\hline From agriculture water resources management to poverty & 0.49 & 0.46 & 7.31 \\
$\mathrm{X}_{2} \rightarrow \mathrm{X}_{1}$ & & & \\
From the property and wealth of producers to poverty & 0.44 & 0.46 & 9.36 \\
$\mathrm{X}_{3} \rightarrow \mathrm{X}_{1}$ & & & 0.052 \\
\hline
\end{tabular}

Table 10: The direct, indirect and total effect in structural model

\begin{tabular}{lcc}
\hline Path & Direct & Total \\
\hline From agriculture water resources management to poverty & 0.49 & - \\
$X_{2} \rightarrow X_{1}$ & 0.49 \\
From the property and wealth of producers to poverty & 0.44 & - \\
$X_{3} \rightarrow X_{1}$ & & 0.44
\end{tabular}

$\mathrm{X}_{3} \rightarrow \mathrm{X}_{1}$

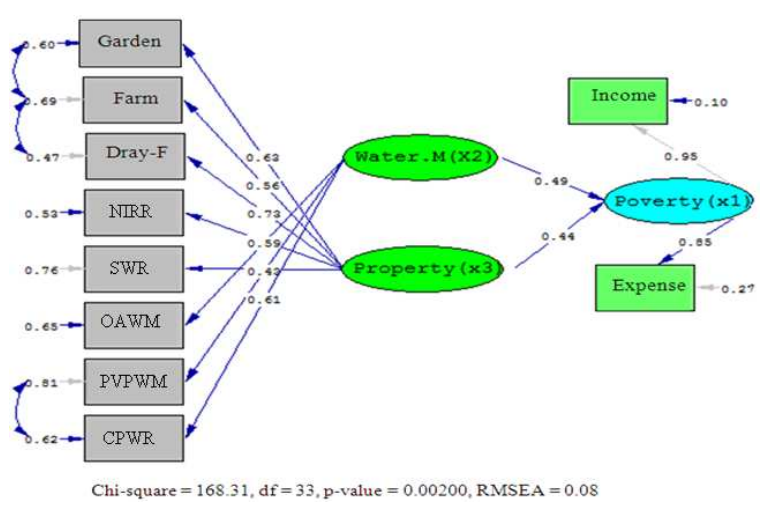

Fig. 2: Structural model of abolish poverty

By using Structural Equation Model (SEM) clear that the most direct and total effect related to agriculture water resources managements with $\mathrm{SS}=0.49$ and this factors are the most effect in explaining the model (Table 10).

Parameters indicated an acceptable to good model fit (Table 11 and Fig. 2).

\section{Structural equations:}

$\operatorname{Poverty}\left(\mathrm{X}_{1}\right)=$

$\begin{array}{ll}0.49 \text { water. } \mathrm{M}\left(\mathrm{X}_{2}\right)+0.44 * \text { property } \\ (0.063) & (0.052)\end{array}$

$\begin{array}{lll}7.31 & 9.36 & 7.83\end{array}$
Table 11: Suitability indicators in structural poverty alleviation model

\begin{tabular}{lr}
\hline Goodness of fit test & Amount \\
\hline Normal theory weighted least squares chi-square & 163.310 \\
P-value & 0.020 \\
Degrees of freedom & 33.000 \\
Root Mean Square Error of Approximation (RMSEA) & 0.080 \\
Comparative Fit Index (CFI) & 0.890 \\
Normal Fit Index (NFI) & 0.860 \\
Goodness of Fit Index (GFI) & 0.910 \\
Adjusted Goodness of Fit Index (AGFI) & 0.850 \\
\hline
\end{tabular}

\section{DISCUSSION}

As the ordinal factor analysis showed, the factors were categorized into four groups, namely finance and economic problems, planning, extension and education and natural ordered by the magnitude of their impact.

The findings show that economical and finance factors are the most important, a result that echoes of (Vinod, 2006; Ward et al., 2005; Varma et al., 2006).

Planning factors are always potentially playing an important role in the optimizing agriculture water resource management. Rijsberrman et al. (2006) believe that in order to integrated water resources management, planning is the principle factors.

The results of ordinal factor analysis show that technical and practical factors are the most important for empowering producers in agricultural water 
resources management, a result that echoes of Smith (2004) pointed out that water management can be greatly improved if the capacities, skills and perspectives of water users are promoted.

Structural equation model is expected to be useful for designing targeted optimizing agricultural water resources management and poverty alleviation strategies that also clear that in alleviation of poverty the most direct and total efficiency related to agriculture water resources managements. Biswas et al. (2003) believe that Poverty is a complex issue, which must be understood in a holistic manner. Low and variable income is certainly a key element, but it is far from enough to portray poverty (Ahmad, 2003; Hussain and Hanjra, 2003; 2004; Rijsberman, 2003; Hussain, 2004).

\section{CONCLUSION}

Access to water in equitable manner and the improved management of water are imperative to sustainable development, poverty alleviation and biodiversity preservation.

Water and poverty interface in many different ways. Sustainable management (i.e., development, allocation and utilization) of water resources is therefore a process-element of sustainable human development.

It is argued that there is not a single silver bullet to reduce poverty though water resources development or management. The best chance for lasting and sustainable impact on poverty is likely to be achieved through a combination of sustainable water resources development, combined with the development of appropriate pro-poor institutions and technologies.

Finally we argue that the antipoverty impact of irrigation water can, therefore, be intensified through triggering a set of board and targeted interventions, simultaneously.

\section{REFERENCES}

Ahmad, Q.K., 2003. Towards poverty alleviation: The water sector perspectives. Int. J. Water Resour. Dev., 18: 263-277. http://www.ingentaconnect.com/content/routledg/ci jw/2003/00000019/00000002/art00014

Akpabio, E.A., N.M. Watson, U.E. Ire and I.E. Ukpong, 2007. Integrated water resources management in the cross river basin, Nigeria. Int. J. Water Resour. Dev., 23: 691-708. DOI: $10.1080 / 07900620701488612$
Biswas, A.K., A. Shady, J. Lundqvist and K. Takahashi, 2003. Workshop 3 (synthesis): Water, poverty alleviation and social programs. Water J. Sci. Technol. Abst., 47: 129-132. http://www.ncbi.nlm.nih.gov/pubmed/12731781

Carriger, S., 2005. Reducing Poverty through Integrated Management of Ground Water and Surface Water. An Opportunity to Improve Equity, Efficiency and Sustainability in Irrigated Areas. 1st Edn., Water Policy Briefing, IWMI., 13, Colombo, Sri Lanka, pp: 8 .

Clothier, B.E., 2000. Globalization of water management. Agric. Water Manage., 45: 215-216.

FAO., 2003. Sustainable water resource management for food security in the Near East region. Proceeding of the High-Level Technical Workshop on Regional Programs for Food Security in the Near East: Toward Sustainable Food Security and Poverty Alleviation, Oct. 8-9, FAO, Jeddah, pp: 12. http://www.Fao.org.ir/

Giordano, M., 2007. Agricultural water policy in China: Challenges. Issues and options. J. Water Policy Abst., 9: $1-9$. http://cat.inist.fr/?aModele $=$ afficheN\&cpsidt $=184547$ 86

Hussain, I. and M.A. Hanjra, 2003. Does irrigation water matter for rural poverty alleviation? Evidence from South and South-East Asia. J. Water Policy Abst., 5: 429-442. http://cat.inist.fr/?aModele $=$ afficheN\&cpsidt $=1534$ 2068

Hussain, I. and M.A. Hanjra, 2004. Irrigation and poverty alleviation: Review of the Emprical evidence. Irrigat. Drain., 53: 1-15. DOI: 10.1002/ird. 114

Hussain, I., 2004. Assessing impacts of irrigation on poverty: Approaches, methods, case studies and lessons. Proceeding of the Workshop on International Water Management Institute (IWMIBOKU-Sieberdorf-EARO-Arbamintch University Collaborative Study on the Impact of Irrigation Development on Poverty and Environment, Apr. 26-30, Ethiopia, pp: 1-9. http://www.iwmi.cgiar.org/propoor/files/ADB_Proj ect/Research_Papers/poverty\%20paper\%20ethiopia.pdf

Hussain, I., D. Wijerathna, S.S. Arif, Murtiningrum, A. Mawarni, and Suparmi, 2006. Irrigation, productivity and poverty linkages in irrigation systems in Java, Indonesia. Water Resour. Manage., 20: 313-36. DOI: 10.1007/s11269-0060079-z 
Hussain, I., M. Giordon and M.A. Hanjra, 2004. Agriculture water and poverty linkages: Care studies on large and small systems. http://www.Iwmi.cgiar.org/propoor/files/ADB_PR OJECT/Researchpapers/Agricultural_water_povert y_linkages.PDF

Keshavarz, A., N. Heydari and S. Ashrafi, 2003. Management of agricultural water consumption, drought and supply of water for future demands. Proceeding of 7 th International Conference on the Development of Dry Land, Sept. 14-17, DDL Press, Tehran, Iran, pp: 42-48.

MalakMohammadi, I., 2009. Toward clean sustainable development to prevent the first food world war changing. authorities-public extension to literalized- partnership extension system. Am. J. Agric. Biol. Sci., 4: 49-62. http://www.scipub.org/fulltext/AJAB/AJAB414962.pdf

Molden, D., M. Burton and M.G. Bos, 2007. Performance assessment, irrigation service delivery and poverty reduction: Benefits of improved system management. Irrigat. Drain. 56: 307-320. DOI: $10.1002 /$ ird.313

Ommani, A.R., 2008. Identifying extension mechanisms for supporting Sustainable Water Resource Management (SWRM) in agriculture in Khuzestan, province. Ph.D. Thesis, Islamic Azad University, Science and Research Branch, Iran.

Raghfar, H., 2007. Poverty in Iran 1989-2007. Soc. Welfare Q., 6: 57-71.

Rahaman, M.M., O. Varis and T. Kajander, 2004. EU water framework directive Vs integrated water resources management: The seven mismatches. Int. J. Water Resour. Dev., 20: 565-575. DOI: 10.1080/07900620412331319199

Rijsberman, F., 2003. Can development of water resources reduce poverty? J. Water Policy Abst., 5: 399-412.

http://cat.inist.fr/?aModele $=$ afficheN\&cpsidt $=1534$ 2066
Rijsberman, F., N. Manning and S.D. Silva, 2006. Baseline document increasing green and blue water productivity to balance water for food and environment. Proceeding of the 4th World Water Forum Water, Food and Environment, Jan. 18-18, IWMI Press, pp: 1-6.

Shen, D. and O. Varis, 2000. World water vision: Balancing thoughts after Hague. Ambio, 34: 523-525. http://www.jstor.org/stable/4315087

Smith, L.D., 2004. Assessment of the contribution of irrigation to poverty reduction and sustainable livelihoods. Int. J. Water Resour. Dev., 20: 243-257. DOI: 10.1080/0790062042000206084

Statistics Center Iran (SCI), 2007. Population and housing census, national portal of statistics. http://www.amar.org.ir/portal/faces/public/census8 5/census85.natayej

Takashi, K., 2001. Globalization and management of water resources: Development opportunities and constraints of diversified developing countries. Int. J. Water Resour. Dev., 17: 481-487. DOI: 10.1080/07900620120094118

UNDP., 2004. Water governance for poverty reduction. Key Issues and the UNDP Response to Millennium Development Goals. http://www.undp.org/water

Varma, S., S. Verma and R.E. Namara, 2006. Promoting Micro-Irrigation Technologies that Reduce Poverty. 1st Edn., Water Policy Briefing, 23, IWMI., Colombo, Sri Lanka, pp: 8.

Vinod, T., 2006. Water Management in Agriculture: Ten years of World Bank Assistance, 1994- 2004. World Bank, Washington, DC., pp: 144. http://www.worldbank.org/ieg

Ward, Ch., S. Dargought, G. Minasyan and G. Gambarelli, 2005. Reneging in Agricultural Water Management: Challenges, Opportunities and Trade-Offs. Agriculture and Rural Development (ARD). The World Bank, World Bank, Washington DC., pp: 7. 